\title{
Potensi Kekayaan Intelektual Dalam Pengembangan Usaha Mikro, Kecil, dan Menengah
}

\author{
Sudjana \\ Fakultas Hukum Universitas Padjadjaran \\ Email: sdjana@yahoo.com
}

Received : 15 Mar 2021 | Revised : 3 Apr 2021 | Accepted : 23 Apr 2021 | Published : 10 Jun 2021

\begin{abstract}
MSMEs occupies an important position in supporting the nation's economy because it needs to be developed continuously so that it becomes a strong and independent business so that it can improve its welfare. Efforts to develop these businesses are carried out by creating original, different and new creations and innovations that have the potential to acquire Intellectual Property. Research methods: normative juridical approach by examining library materials; research stage: library study, namely reviewing secondary data; and analysis methods: qualitative normative that describes the data obtained and then analyzes based on the legal aspects. The results of the study show that the development of MSMEs according to positive laws is carried out by the Government and Regional Governments in facilitating the production and processing sector; marketing; human Resources; and design and technology. Meanwhile, the business world and the community play an active role in carrying out development which includes development procedures, priorities, intensity, and development period. Creations and innovations of MSMEs related to intellectual property if they meet the requirements have the potential to obtain trade secrets, trademarks, copyrights, industrial designs and patents.
\end{abstract}

Keywords: Intellectual Property Law, Development, MSMEs

\begin{abstract}
ABSTRAK
UMKM menempati posisi penting dalam menunjang perekonomian bangsa karena itu perlu dikembangkan secara berkesinambungan agar menjadi usaha yang tangguh dan mandiri sehingga dapat meningkatkan kesejahteraannya. Upaya mengembangan usaha tersebut dilakukan dengan menciptakan kreasi dan inovasi yang asli, berbeda, dan baru sehingga berpotensi mendapat Kekayaan Intelektual. Metode Penelitian: pendekatan yuridis normatif dengan meneliti bahan pustaka; tahap penelitian: studi perpustakaan yaitu mengkaji data sekunder; dan metode analisis: normatif kualitatif yaitu mendeskripsikan data yang diperoleh kemudian menganalisis berdasarkan aspek hukumnya. Hasil kajian menunjukan bahwa pengembangan UMKM menurut hukum Positif dilakukan oleh Pemerintah dan Pemerintah Daerah dalam memfasilitasi bidang produksi dan pengolahan; pemasaran; sumber daya manusia; dan desain dan teknologi. Sedangkan Dunia usaha dan masyarakat berperan aktif melakukan pengembangan yang mencakup tata cara pengembangan, prioritas, intensitas, dan jangka waktu pengembangan. Kreasi dan inovasi UMKM berkaitan dengan kekayaan intelektual apabila memenuhi persyaratan berpotensi memperoleh hak Rahasia Dagang, Merek , Hak Cipta, Desain Industri dan Paten.
\end{abstract}

Kata Kunci: Kekayaan Intelektual, Pengembangan, UMKM 


\section{PENDAHULUAN}

Alinea IV Pembukaan Undang-Undang Dasar 1945 menyebutkan bahwa salah satu tujuan Negara adalah "memajukan kesejahteraan umum" yang harus diwujudkan melalui pembangunan ekonomi berdasarkan demokrasi ekonomi untuk mencapai masyarakat adil dan makmur sebagaimana tercantum dalam Pasal 33 (1) UUD 1945. Demokrasi ekonomi yaitu menghendaki adanya kesempatan yang sama bagi setiap warga negara untuk berpartisipasi di dalam proses produksi dan pemasaran barang dan atau jasa, dalam iklim usaha yang sehat, efektif, dan efisien sehingga dapat mendorong pertumbuhan ekonomi ${ }^{1}$ dan bekerjanya ekonomi pasar yang wajar. Namun peluang-peluang usaha dalam kenyataannya belum membuat seluruh masyarakat mampu dan dapat berpartisipasi dalam pembangunan di berbagai sektor ekonomi, terutama Usaha Mikro, Kecil, dan Menengah (UMKM). Padahal UMKM memiliki peran penting dalam perekonomian masyarakat Indonesia. Moeldoko menjelaskan bahwa "dalam dua tahun ini, jumlah UMKM terus meningkat, Pada 2016 jumlahnya sekitar 57,9 juta sedangkan 2017 mencapai 59 juta. Di Indonesia dan ASEAN, UMKM telah menjadi tulang punggung perekonomian yaitu sekitar 88,8-99,9 persen usaha di ASEAN adalah UMKM. Sektor itu mampu menyerap tenaga kerja di kisaran 51,7 - 97,2\%". ${ }^{2}$ UMKM menyumbang terhadap PDB hingga $60,34 \%$ dari jumlah usaha kecil di Indonesia yang mencapai 93,4\% persen, usaha menengah $5,1 \%$, dan usaha besar hanya $1 \%$ persen. ${ }^{3}$ Data dari Kementerian Koperasi dan UKM tahun 2017, devisa negara dari UMKM mencapai Rp.88,45 miliar, mengalami peningkatan hingga delapan kali lipat dibandingkan tahun 2016. Sedangkan menurut Centre for Strategic and International Studies (CSIS) di kawasan Asia Pasifik, Data dari Bank Pembangunan Asia (ADB) menunjukkan rerata UMKM berkontribusi hingga $62 \%$ dari lapangan kerja dengan populasi sekitar $96 \%$ dari total perusahaan di 20 negara kawasan Asia Pasifik. Kontribusi UMKM terhadap ekspor di berbagai negara kawasan Asia Pasifik cukup tinggi, angkanya mencapai $40 \%$ di China dan India, 26\% di Thailand dan 19\% di Korea Selatan, dan di Indonesia, mencapai $16 \%$.

Berdasarkan data tersebut maka UMKM perlu terus menerus dikembangkan secara berkesinambungan, untuk meningkatkan kualitas produk sehingga menjadi usaha yang tangguh dan mandiri. Pemberdayaan UMKM perlu diselenggarakan secara menyeluruh, optimal, dan berkesinambungan melalui pengembangan iklim yang kondusif, pemberian kesempatan berusaha, dukungan, perlindungan, dan pengembangan usaha seluas-luasnya, sehingga mampu meningkatkan kedudukan,

\footnotetext{
${ }^{1}$ Kebijakan yang lebih terfokus kepada pencapaian target pertumbuhan (economic growth) telah mengakibatkan pemerintah lebih mengutamakan perkembangan perusahaan besar dengan tujuan untuk menghasilkan devisa. Kebijakan tersebut dilaksanakan dengan asumsi bahwa pertumbuhan nantinya dengan sendirinya akan melahirkan pemerataan kesejahteraan bagi rakyat, sesuai dengan teori tricle down efect. Lihat Yoserwan, Hukum Ekonomi Indonesia, Dalam Era Reformasi dan Globalisasi, Andalas University Press, Padang 2006, hlm 93-94. Lihat juga Laurensius Arliman S, Perlindungan Hukum UMKM Dari Eksploitasi Ekonomi Dalam Rangka Peningkatan Kesejahteraan Masyarakat, Jurnal Rechvinding, Media Pembinaan Hukum Nasional, Volume 6, Nomor 3, Desember 2017, h. 389, https://rechtsvinding.bphn.go.id/artikel/05\%20Laurensius\%20 Arliman.pdf diakses 7 Januari 2021.

${ }^{2}$ http: //krjogja.com/web/news/read/55319/ Begini_Peranan_UMKM_dalam_Perekonomian _Nasional. diakses 6 Desember 2020.

${ }^{3}$ https://www.liputan6.com/bisnis/read/3581067/umkm-sumbang-60-persen-ke-pertumbuhanekonomi-nasional. diakses 10 Desember 2020.

4 Hikman Dwi R, 3 Alasan Mengapa UMKM Penting bagi Perekonomian Indonesia, https://kumparan.com/hikman-dwi-r/3-peran-penting-umkm-penggerak-sektor-ekonomi-indonesia-ditingkat-menengah-ke-bawah diakses 12 Desember 2020.
} 
peran, dan potensi UMKM dalam mewujudkan pertumbuhan ekonomi, pemerataan dan peningkatan pendapatan rakyat, penciptaan lapangan kerja, dan pengentasan kemiskinan ${ }^{5}$. Hal ini sejalan dengan amanat Ketetapan Majelis Permusyawaratan Rakyat Republik Indonesia Nomor XVI/MPR-RI/1998 Tentang Politik Ekonomi dalam rangka Demokrasi Ekonomi, UMKM perlu diberdayakan sebagai bagian integral ekonomi rakyat yang mempunyai kedudukan, peran, dan potensi strategis untuk mewujudkan struktur perekonomian nasional yang makin seimbang, berkembang, dan berkeadilan sesuai konsep Negara kesejahteraan (welfare state).

Kekayaan Intelektual (KI) di lingkungan pelaku usaha (UMKM) sering dipahami sebagai aset perusahaan karena KI dikualifikasikan sebagai aset tidak berwujud (intangible assets). Dalam konteks kegiatan usaha, KI memegang peranan penting karena sebagai salah satu pendorong bagi kegiatan bisnis selain sumber daya manusia, sumber daya finansial, aset berwujud (tangible assets). ${ }^{6}$ Pentingnya KI bagi kegiatan bisnis, tidak hanya untuk pelaku usaha besar saja tetapi juga untuk pelaku UMKM sebagaimana diatur dalam UU No 20 Tahun 2008.

Keterkaitan KI dengan UKM terungkap dalam beberapa forum internasional misalnya: The WIPO ASEAN Sub Regional Policy Forum tanggal 25-27 Juli 2000 di Bali dengan rekomendasi yang tercantum dalam Statement terlampir dalam Lampiran IV. Forum terakhir adalah hasil bahasan dari WIPO General Assemblies tanggal 24 September di Jenewa yang intinya tercantum dalam press-release Lampiran V. Sementara itu dari WIPO Forum Intellectual Property and Small and Medium-Sized Enterprises tanggal 9-10 Februari 2001 yang dilaksanakan di Milan dikeluarkan rekomendasi yang mendukung program kaitan antara SME dan kekayaan intelektual (Lampiran VI). ${ }^{7}$

Pengembangan UMKM dalam menghasilkan kreasi produk, berpotensi untuk mendapatkan perlindungan kekayaan intelektual yaitu perlindungan yang diberikan terhadap kreasi atau produk hasil kecerdasan, daya pikir manusia melalui penggunaan intelektualnya dibidang ilmu pengetahuan, seni, sastera, bisnis, industri dan teknologi berdasarkan syarat-syarat tertentu. Berdasarkan hal itu, identifikasi masalah dalam kajian ini adalah “

1. Bagaimana pengembangan UMKM berdasarkan hukum positif?.

2. Bagaimana potensi UMKM untuk mendapatkan perlindungan kekayaan intelektual?

\section{METODE PENELITIAN}

Metode pendekatan yuridis normatif yaitu berdasarkan bahan hukum utama dengan cara menelaah teori-teori, konsep-konsep, asas-asas hukum serta peraturan perundangundangan yang berhubungan dengan kajian yang dibahas. Tahap penelitian dilakukan melalui studi kepustakaan dengan mengkaji bahan pustaka ${ }^{8}$, yakni menggunakan Menengah.

${ }^{5}$ Bagian Menimbang Huruf c UU No 20 Tahun 2008 tentang Usaha Mikro, Kecil dan

${ }^{6}$ Nurhasanah Harahap, Relevansi Hak Kekayaan Intelektual Untuk Usaha Kecil Menengah (UKM), https://nurhasanahharahap 25212492.wordpress.com/2014/04/11/ relevansi-hak-kekayaanintelektual-untuk-usaha-kecil-menengah-ukm.diakses 20 Desember 2020.

${ }^{7}$ Ibid.

8 Soerjono Soekanto dan Sri Mamudji, Penelitian Hukum Normatif Suatu Tinjauan Singkat, Cetakan ke - 11, Jakarta : PT Raja Grafindo Persada, 2009, hlm 13-14. 
berbagai data sekunder yaitu Bahan hukum primer seperti peraturan perundangundangan, Bahan hukum sekunder yaitu teori hukum, dan pendapat para akhli serta bahab hukum tersier seperti sumber digital (internet). Penelitian jenis normatif ini menggunakan metode analisis normatif kualitatif yakni dengan menjelaskan datadata yang ada dengan kata-kata atau pernyataan berkaitan dengan aspek hukumnya bukan dengan angka-angka. ${ }^{9}$

\section{PEMBAHASAN}

\section{Pengembangan UMKM berdasarkan Hukum Positif}

Usaha Mikro adalah usaha produktif milik orang perorangan dan/atau badan usaha perorangan yang memenuhi kriteria:

a. Memiliki kekayaan bersih paling banyak Rp50.000.000,00 (lima puluh juta rupiah) tidak termasuk tanah dan bangunan tempat usaha; atau

b. memiliki hasil penjualan tahunan paling banyak Rp300.000.000,00 (tiga ratus juta rupiah).

Usaha Kecil adalah usaha ekonomi produktif yang berdiri sendiri, yang dilakukan oleh orang perorangan atau badan usaha yang bukan merupakan anak perusahaan atau bukan cabang perusahaan yang dimiliki, dikuasai, atau menjadi bagian baik langsung maupun tidak langsung dari Usaha Menengah atau Usaha Besar yang memenuhi kriteria:

a. memiliki kekayaan bersih lebih dari Rp50.000.000,00 (lima puluh juta rupiah) sampai dengan paling banyak Rp500.000.000,00 (lima ratus juta rupiah) tidak termasuk tanah dan bangunan tempat usaha; atau

b. memiliki hasil penjualan tahunan lebih dari Rp300.000.000,00 (tiga ratus juta rupiah) sampai dengan paling banyak Rp2.500.000.000,00 (dua milyar lima ratus juta rupiah).

Usaha Menengah adalah usaha ekonomi produktif yang berdiri sendiri, yang dilakukan oleh orang perorangan atau badan usaha yang bukan merupakan anak perusahaan atau cabang perusahaan yang dimiliki, dikuasai, atau menjadi bagian baik langsung maupun tidak langsung dengan Usaha Kecil atau Usaha Besar dengan jumlah:

a. memiliki kekayaan bersih lebih dari Rp500.000.000,00 (lima ratus juta rupiah) sampai dengan paling banyak Rp10.000.000.000,00 (sepuluh milyar rupiah) tidak termasuk tanah dan bangunan tempat usaha; atau

b. memiliki hasil penjualan tahunan lebih dari Rp2.500.000.000,00 (dua milyar lima ratus juta rupiah) sampai dengan paling banyak Rp50.000.000.000,00 (lima puluh milyar rupiah).

Menurut perkembangannya UMKM dapat dikelompokkan menjadi empat kelompok yaitu livelyhood activity (sektor informal); micro enterprise small (pengrajin); dynamic enterprise (telah mampu sebagai subkontraktor) memiliki jiwa kewirausahaan); dan fast moving enterprise (transformasi menjadi usaha besar). ${ }^{10}$

9 https://idtesis.com/pengertian-penelitian-hukum-normatif-adalah/ diakses 15 Desember

${ }^{10}$ Selengkapnya lihat Djasuro Surya, Manajemen Koperasi dan UKM, Serang: Untirta Press, 2015. Sebagaimana dikutip oleh Gunartin, "Penguatan UMKM Sebagai Pilar Membangun Ekonomi Bangsa", EDUKA Jurnal Pendidikan, Hukum dan Bisnis Vol.1 No. V Desember 2017, hlm 64-65. lihat 
Pengembangan ${ }^{11}$ adalah upaya yang dilakukan oleh Pemerintah ${ }^{12}$, Pemerintah Daerah, Dunia Usaha, dan masyarakat untuk memberdayakan UMKM melalui pemberian fasilitas, bimbingan, pendampingan, dan bantuan perkuatan untuk menumbuhkan dan meningkatkan kemampuan dan daya saing UMKM. ${ }^{13}$

\section{Prinsip pemberdayaan UMKM: ${ }^{14}$}

a. penumbuhan kemandirian, kebersamaan, dan kewirausahaan UMKM untuk berkarya dengan prakarsa sendiri;

b. perwujudan kebijakan publik yang transparan, akuntabel, dan berkeadilan;

c. pengembangan usaha berbasis potensi daerah dan berorientasi pasar sesuai dengan kompetensi UMKM;

d. peningkatan daya saing UMKM; dan

e. penyelenggaraan perencanaan, pelaksanaan, dan pengendalian secara terpadu. Tujuan pemberdayaan UMKM $:^{15}$

a. mewujudkan struktur perekonomian nasional yang seimbang, berkembang, dan berkeadilan;

b. menumbuhkan dan mengembangkan kemampuan UMKM menjadi usaha yang tangguh dan mandiri; dan

c. meningkatkan peran UMKM dalam pembangunan daerah, penciptaan lapangan kerja, pemerataan pendapatan, pertumbuhan ekonomi, dan pengentasan rakyat dari kemiskinan.

Problematika pengembangan UMKM berkaitan dengan 7 (tujuh) faktor atau karakteristik yaitu: ${ }^{16}$ kesulitan pemasaran; keterbatasan finansial; keterbatasan SDM; masalah bahan baku. keterbatasan teknologi; keterbatasan kemampuan untuk menentukan pola manejemen yang sesuai; dan Kemitraaan. Oleh karena itu Pemerintah dan Pemerintah Daerah memfasilitasi pengembangan UMKM di bidang: produksi dan pengolahan; pemasaran; sumber daya manusia; dan desain dan teknologi sedangkan Dunia usaha dan masyarakat berperan serta secara aktif melakukan pengembangan. Adapun tata cara pengembangan, prioritas, intensitas, dan jangka waktu pengembangan mengacu pada Peraturan Pemerintah Republik Indonesia Nomor 32 Tahun 1998 Tentang Pembinaan dan Pengembangan Usaha

juga Sudaryanto dkk, "Strategi Pemberdayaan UMKM Menghadapi Pasar Bebas Asean", Jurnal Kementrian Keuangan Republik Indonesia (DI) tersedia dari https://www.kemenkeu. go.id/sites/default/files/strategi\%20pemberdayaan\%20umkm.pdf diakses 6 Januari 2021.

11 Pengembangan dapat diartikan sebagai suatu usaha untuk meningkatkan kemampuan konseptual, teoritis, teknis, dan moral individu sesuai dengan kebutuhan pekerjaan atau jabatan melalui pendidikan dan pelatihan. mengemukakan bahwa pengembangan UKM lebih diarahkan untuk menjadi pelaku ekonomi yang berdaya saing melalui perkuatan kewirausahaan dan peningkatan produktivitas yang didukung dengan upaya peningkatan adaptasi terhadap kebutuhan pasar, pemanfaatan hasil inovasi dan penerapan teknologi. Lihat Afifuddin, Pengantar Administrasi Pembangunan, Bandung: CV Alfabeta, 2010, hlm 180.

12 Pengaruh dari pengembangan UMKM di Indonesia dan melihat peran serta pemerintah dalam meningkatkan pertumbuhan UMKM di Indonesia memiliki hasil positif, baik secara langsung maupun tidak langsung. Lihat Tambunan, T, UMKM di Indonesia, Bogor : Ghalia, 2009, hlm 4. Lihat juga Alyas dan Muhammad Rakib, "Strategi Pengembangan Usaha Mikro, Kecil Dan Menengah Dalam Penguatan Ekonomi Kerakyatan" (Studi Kasus pada Usaha Roti Maros di Kabupaten Maros), Jurnal Sosiohumaniora, Volume 19 No. 2 Juli 2017, hlm114 - 120.

${ }^{13}$ Pasal 1 angka 10 UU UMKM.

${ }^{14}$ Ibid, Pasal 4.

${ }^{15}$ Ibid, Pasal 5.

${ }^{16}$ Penjelasan selengkapnya lihat Musa Hubeis, Prospek Usaha Kecil Dalam Wadah Inkubator Bisnis: Bogor: Ghalia Indonesia, 2015, hlm 4-10. 
Kecil sebagai Peraturan Pelaksana UU UMKM yang lama yaitu UU No 9 Tahun 1995 Tentang Usaha Kecil, karena Peraturan Pemerintah sebagai pelaksana UU No 20 Tahun 2008 belum disahkan.

Pembinaan dan pengembangan UMKM dilakukan oleh pemerintah, dunia usaha dan masyarakat, baik secara sendiri-sendiri maupun bersama-sama, dan dilakukan secara terarah dan terpadu serta berkesinambungan untuk mewujudkan usaha kecil yang tangguh dan mandiri serta dapat berkembang menjadi usaha menengah. Pembinaan dan pengembangan usaha kecil pada dilaksanakan dengan memperhatikan klasifikasi dan tingkat perkembangan usaha kecil yang ditetapkan bobot, intensitas, prioritas dan jangka waktu pembinaan dan pengembangan usaha kecil.

Ruang lingkup pembinaan dan strategi ${ }^{17}$ pengembangan UMKM meliputi bidang produksi dan pengolahan, pemasaran, sumber daya manusia dan teknologi yang dilakukan melalui langkah-langkah sebagai berikut:

a. identifikasi potensi dan masalah yang dihadapi oleh usaha kecil;

b. penyiapan program pembinaan dan pengembangan sesuai potensi dan masalah yang dihadapi oleh usaha kecil;

c. pelaksanaan program pembinaan dan pengembangan;

d. pemantauan dan pengendalian pelaksanaan program pembinaan dan pengembangan bagi usaha kecil.

Campur tangan Pemerintah dan pengembangan UMKN sesuai konsep Negara kesejahteraan (welfare state) yang ide dasarnya berasal pada upaya negara untuk mengelola semua sumber daya yang ada demi mencapai salah satu tujuan negara yaitu meningkatkan kesejahteraan rakyatnya, ${ }^{18}$ sehingga peran pemerintah bertanggungjawab dalam mengelola dan mengorganisasikan perekonomian. Dengan demikian, negara diharapkan mampu menjalankan tanggungjawabnya untuk menjamin ketersediaan pelayanan kesejahteraan dasar dalam tingkat tertentu bagi warganya. ${ }^{19}$ Negara kesejahteraan yang dianut Indonesia adalah "Negara Kesejahteraan Partisipatif" (participatory welfare state) dalam arti model ini menekankan bahwa Negara harus aktif dalam penyelenggaraan jaminan sosial (sosial security), tetapi operasionalisasinya melibatkan peran masyarakat.

\section{Potensi UMKM untuk mendapatkan Perlindungan Kekayaan Intelektual}

Dalam literatur hukum Anglo Saxon dikenal istilah Intellectual Property Rights, yang diterjemahkan ke dalam bahasa Indonesia menjadi dua macam istilah hukum: "Hak Milik Intelektual" (HMI dan "Hak Atas Kekayaan Intelektual" (HAKI), tetapi pada

${ }^{17}$ Strategi berkaitan dengan keputusan yang dihadapi indvidu atau organisasi dalam melakukan bisnis yaitu keputusan yang menentukan kegagalan dan kesuksesan individu atau organisasi. Lihat Kuncoro, M, Strategi Bagaimana Meraih Keunggulan Kompetitif, Jakarta: Erlangga, 2005, hlm 265. Strategi diartikan sebagai tindakan potensial yang membutuhkan keputusan manajemen tingkat atas dan sumber daya perusahaan dalam jumlah yang besar. Lihat David, F.R, Manajemen Strategi; Konsep, Edisi Kesepuluh, Jakarta: Salemba Empat 2006, hlm17.

${ }^{18}$ Oman Sukmana, "Konsep dan Desain Negara Kesejahteraan (Welfare State)”, Jurnal Sospol, Vol 2 No.1 (Juli-Desember 2016), hlm 103-122, tersedia dalam http://ejournal.umm.ac.id/ index.php/sospol/article/ view/4759/4900 diakses 21 Desember 2020.

19 Ariza Fuadi, "Negara Kesejahteraan (Welfare State) Dalam Pandangan Islam Dan Kapitalisme" Jurnal Ekonomi Syariah Indonesia, Volume V, No.1 Juni 2015 tersedia dari ejournal.umm.ac.id/index.php/JES/article/view/8741 diakses 23 Desember 2020. 
saat ini digunakan istilah 'Kekayaan Intelektual (KI).' McKeough and Stewart mendefinisikan KI sebagai hak yang memberikan perlindungan hukum atas hasil kreatifitas manusia yang memiliki manfaat ekonomi. Sementara Lyle Glowka mendefinisikan KI adalah hak hukum privat yang memberikan penghargaan atas kontribusi manusia tidak berwujud yang akan digunakan untuk memproduksi suatu teknologi yang bersifat khusus. ${ }^{20}$

Perjanjian TRIPs tidak mendefinisikan kekayaan intelektual, tetapi dalam Pasal 1-2 menyebutkan bahwa kekayaan intelektual terdiri dari: a. Hak cipta dan hakhak yang berkaitan dengan hak cipta (seperti hak dari seni pertunjukan, produser rekaman suara dan organisasi penyiaran); b. Merek; c. Indikasi Geografis; d. Desain Industri; e. Paten; f. Desain Tata Sirkuit Terpadu; g. Rahasia Dagang dan Data Mengenai Test (Test Data) h. Varietas Tanaman Baru. ${ }^{21}$

Pembagian Ruang lingkup KI lainnya, dikelompokan kedalam dua bagian. Pertama, Pengelompokan tradisional yang memakai acuan yang berasal dari WIPO dengan melihat dari ketentuan yang mengaturnya dalam Konvensi mengenai Hak Cipta (Konvensi Bern 1886), dan Konvensi Paris tentang Hak Perindustrian. Kedua, Pengelompokan berdasarkan sumber hukumnya. ${ }^{22}$ Pada dasarnya KI digolongkan kedalam dua bagian, pertama adalah Hak Cipta dan hak-hak yang terkait dengan Hak Cipta (Neighboring Rights). Kedua adalah Kekayaan Perindustrian (Industrial Property Rights) yang khusus berkaitan dengan industry yang terdiri dari:

1. Hak Cipta dan Hak Terkait

2. Kekayaan Perindustrian

a. Paten

b. Merek

c. Perlindungan Varietas Tanaman

d. Rahasia Dagang

e. Desain Industri

f. Desain Tata Letak Sirkuit Terpadu

Penggolongan tersebut bertujuan untuk memudahkan pemahaman tentang KI berdasarkan sifat tradisionalnya yang terjadi dalam praktik negara-negara, karena WIPO sebagai organisasi dunia di bidang KI sebenarnya tidak melakukannya. Pengelompokan tersebut bersifat tradisional karena sesuai dengan sejarah KI, yang beranggapan adanya hak yang berkaitan erat dengan kegiatan industri atau tidak.

Pengembangan UMKM meliputi: produksi dan pengolahan, pemasaran, sumber daya manusia, desain dan teknologi. Apabila dikaitkan dengan rezim Kekayaan Intelektual, maka dapat dijelaskan sebagai berikut:

\section{Produksi dan Pengolahan}

Pembinaan dan pengembangan UMKM di bidang produksi dan pengolahan, dilaksanakan dengan:

a. meningkatkan kemampuan manajemen serta teknik produksi dan pengolahan;

b. meningkatkan kemampuan rancang bangun dan perekayasaan;

\footnotetext{
${ }^{20}$ Andrian Krisnawati dan Gazalba Saleh, Perlindungan Hak Varietas Tanaman Baru Dalam Prespektif Hak Paten dan Hak Pemuliaan Tanaman, Jakarta: PT. Raja Grafindo Persada, 2004, hlm 14.

${ }^{21}$ Suyud Margono, Aspek Hukum Komersialisasi Aset Intelektual, Bandung: Penerbit Nuansa Aulia, 2010, hlm 12.

${ }^{22}$ Ibid, h. 22-23.
} 
c. memberikan kemudahan dalam pengadaan sarana dan prasarana produksi dan pengolahan, bahan baku, bahan penolong, dan kemasan;

d. menyediakan tenaga konsultan profesional di bidang produksi dan pengolahan.

Produksi dan Pengolahan yang dilaksanakan sesuai dengan poin a s/d d berkaitan dengan Rahasia Dagang apabila "dirahasiakan" sehingga berpotensi mendapatkan Hak Rahasia Dagang ${ }^{23}$, karena Lingkup perlindungan Rahasia Dagang meliputi metode produksi, metode pengolahan, metode penjualan, atau informasi lain di bidang teknologi dan/atau bisnis yang memiliki nilai ekonomi dan tidak diketahui oleh masyarakat umum. Rahasia Dagang, yaitu "informasi yang tidak diketahui oleh umum di bidang teknologi dan/atau bisnis, mempunyai nilai ekonomi karena berguna dalam kegiatan usaha, dan dijaga kerahasiaannya oleh pemilik Rahasia Dagang".

Rahasia Dagang mendapat perlindungan apabila informasi tersebut bersifat rahasia, mempunyai nilai ekonomi, dan dijaga kerahasiaannya melalui upaya sebagaimana mestinya. Informasi dianggap bersifat rahasia apabila informasi tersebut hanya diketahui oleh pihak tertentu atau tidak diketahui secara umum oleh masyarakat. Informasi dianggap memiliki nilai ekonomi apabila sifat kerahasiaan informasi tersebut dapat digunakan untuk menjalankan kegiatan atau usaha yang bersifat komersial atau dapat meningkatkan keuntungan secara ekonomi. Informasi dianggap dijaga kerahasiaannya apabila pemilik atau para pihak yang menguasainya telah melakukan langkah-langkah yang layak dan patut. Apabila persyaratan tersebut telah dipenuhi, maka secara otomatis, UMKM memperoleh hak rahasia dagang karena prinsif perlindungannya otomatis, artinya tidak mewajibkan pendaftaran dan jangka waktu perlindungan tidak terbatas. UMKM sebagai Pemilik Rahasia Dagang memiliki hak untuk: a. menggunakan sendiri Rahasia Dagang yang dimilikinya; b. memberikan Lisensi kepada atau melarang pihak lain untuk menggunakan Rahasia Dagang atau mengungkapkan Rahasia Dagang itu kepada pihak ketiga untuk kepentingan yang bersifat komersial.

\section{Pemasaran}

Pembinaan dan pengembangan UMKM di bidang pemasaran, dilaksanakan dengan:

a. melaksanakan penelitian dan pengkajian pemasaran;

b. meningkatkan kemampuan manajemen dan teknik pemasaran;

c. menyediakan sarana serta dukungan promosi dan uji coba pasar;

d. mengembangkan lembaga pemasaran dan jaringan distribusi;

e. memasarkan produk usaha kecil;

f. menyediakan tenaga konsultan profesional di bidang pemasaran;

g. menyediakan rumah dagang dan promosi usaha kecil.

h. memberikan peluang pasar.

Pemasaran yang dilaksanakan sesuai dengan poin a s/d $\mathrm{h}$ berkaitan dengan merek sehingga berpotensi untuk mendapat perlindungan merek $^{24}$, sesuai definisi merek sebagai berikut:" Merek adalah tanda yang dapat ditampilkan secara grafis berupa gambar, logo, nama, kata, huruf, angka, susunan warna, dalam bentuk 2 (dua) dimensi dan/atau 3 (tiga) dimensi, suara, hologram, atau kombinasi dari 2 (dua) atau

${ }^{23}$ UU No 30 Tahun 2000 tentang Rahasia Dagang

${ }^{24}$ UU No 20 Tahun 2016 tentang Merek dan Indikasi Geografis. 
lebih unsur tersebut untuk membedakan barang dan/atau jasa yang diproduksi oleh orang atau badan hukum dalam kegiatan perdagangan barang dan/atau jasa”.

Merek tidak dapat didaftar jika: ${ }^{25}$

a. bertentangan dengan ideologi negara,peraturan perundang-undangan, moralitas, agama, kesusilaan, atau ketertiban umum;

b. sama dengan, berkaitan dengan, atau hanya menyebut barang dan/atau jasa yang dimohonkan pendaftarannya;

c. memuat unsur yang dapat menyesatkan masyarakat tentang asal, kualitas, jenis, ukuran, macam, tujuan penggunaan barang dan/atau jasa yang dimohonkan pendaftarannya atau merupakan nama varietas tanaman yang dilindungi untuk barang dan/atau jasa yang sejenis;

d. memuat keterangan yang tidak sesuai dengan kualitas, manfaat, atau khasiat dari barang dan/atau jasa yang diproduksi;

e. tidak memiliki daya pembeda; dan/atau

f. merupakan nama umum dan/atau lambang milik umum.

Permohonan ditolak jika Merek tersebut mempunyai persamaan pada pokoknya atau keseluruhannya dengan:

a. Merek terdaftar milik pihak lain atau dimohonkan lebih dahulu oleh pihak lain untuk barang dan/atau jasa sejenis;

b. Merek terkenal milik pihak lain untuk barang dan/atau jasa sejenis;

c. Merek terkenal milik pihak lain untuk barang dan/atau jasa tidak sejenis yang memenuhi persyaratan tertentu; atau

d. Indikasi Geografis terdaftar.

Permohonan ditolak jika Merek tersebut:

a. merupakan atau menyerupai nama atau singkatan nama orang terkenal, foto, atau nama badan hukum yang dimiliki orang lain, kecuali atas persetujuan tertulis dari yang berhak;

b. merupakan tiruan atau menyerupai nama atau singkatan nama, bendera, lambang atau simbol atau emblem suatu negara, atau lembaga nasional maupun internasional, kecuali atas persetujuan tertulis dari pihak yang berwenang; atau

c. merupakan tiruan atau menyerupai tanda atau cap atau stempel resmi yang digunakan oleh negara atau lembaga Pemerintah, kecuali atas persetujuan tertulis dari pihak yang berwenang.

Apabila UMKM memiliki merek yang memenuhi persyaratan UU, dalam arti tidak termasuk kategori merek yang tidak dapat didaftar dan tidak alasan untuk penolakan permohonan merek maka UMKM dapat memperoleh hak merek tetapi harus melakukan pendaftaran terlebih dahulu ke Direktorat Jenderal Kekayaan Intelektual karena prinsif perlindungan merek adalah "konstitutif" artinya perlindungan diberikan apabila telah terdaftar. Hak atas Merek adalah hak eksklusif yang diberikan oleh negara kepada pemilik Merek (dalam hal ini adalah UMKM) yang terdaftar untuk jangka waktu tertentu dengan menggunakan sendiri Merek tersebut atau memberikan izin kepada pihak lain untuk menggunakannya. Jangka waktu perlindungan adalah 10 tahun tetapi dapat diperpanjang sesuai dengan ketentuan UU.

${ }^{25}$ Pasal 20 UU Merek dan Indikasi Geografis. 


\section{Sumber Daya Manusia}

Pembinaan dan pengembangan UMKM di bidang sumber daya manusia, dilaksanakan dengan:

a. memasyarakatkan dan membudayakan kewirausahaan;

b. meningkatkan keterampilan teknis dan manajerial;

c. membentuk dan mengembangkan lembaga pendidikan, pelatihan dan konsultasi usaha kecil;

d. menyediakan tenaga penyuluh dan konsultan usaha kecil;

e. menyediakan modul manajemen usaha kecil;

f. menyediakan tempat magang, studi banding dan konsultasi untuk usaha kecil.

Pengembangan UMKM di bidang sumber daya manusia yang dilaksanakan berdasarkan poin a s/d f berkaitan dengan Ilmu Pengetahuan dan seni, berpotensi untuk mendapatkan Hak Cipta ${ }^{26}$." Hak Cipta adalah hak eksklusif pencipta yang timbul secara otomatis berdasarkan prinsip deklaratif setelah suatu ciptaan diwujudkan dalam bentuk nyata tanpa mengurangi pembatasan sesuai dengan ketentuan peraturan perundang-undangan". Ciptaan adalah setiap hasil karya cipta di bidang ilmu pengetahuan, seni, dan sastra yang dihasilkan atas inspirasi, kemampuan, pikiran, imajinasi, kecekatan, keterampilan, atau keahlian yang diekspresikan dalam bentuk nyata.

Hasil karya yang tidak dilindungi Hak Cipta meliputi: a. hasil karya yang belum diwujudkan dalam bentuk nyata; b. setiap ide, prosedur, sistem, metode, konsep, prinsip, temuan atau data walaupun telah diungkapkan, dinyatakan, digambarkan, dijelaskan, atau digabungkan dalam sebuah Ciptaan; dan c. alat, Benda, atau produk yang diciptakan hanya untuk menyelesaikan masalah teknis atau yang bentuknya hanya ditujukan untuk kebutuhan fungsional.

Untuk memperoleh hak cipta tidak memerlukan pendaftaran (prinsip deklaratif) karena hak cipta timbul setelah kreasi tersebut berwujud dan bersifat asli (bukan peniruan). Namun, dalam praktek sering dicatatkan (bukan didaftarkan) ke Direktorat Jenderal Kekayaan Intelektual. Pencatatan hak cipta meskipun bukan merupakan kewajiban tetapi penting berkaitan dengan pembuktian apabila terjadi pelanggaran karena penggugat (pelaku UMKM) harus membuktikan adanya "bukti hak" (melalui alat bukti tulisan "sertifikat hak cipta") sesuai Pasal 1865 KUHPerdata yang berbunyi " Setiap orang yang mengaku mempunyai suatu hak, atau menunjuk suatu peristiwa untuk meneguhkan haknya itu atau untuk membantah suatu hak orang lain, wajib membuktikan adanya hak itu atau kejadian yang dikemukakan itu".

Pelaku UMKM yang telah memperoleh hak cipta memiliki kualifikasi sebagai "pencipta", yaitu "seorang atau beberapa orang yang secara sendiri-sendiri atau bersama-sama menghasilkan suatu ciptaan yang bersifat khas dan pribadi”. Dalam hal pelaku UMKM mengalihkan hak cipta tersebut kepada pihak lain secara sah, maka pihak lain tersebut adalah "pemegang hak cipta". Dengan demikian Pemegang Hak Cipta adalah Pencipta sebagai pemilik Hak Cipta, pihak yang menerima hak tersebut secara sah dari Pencipta, atau pihak lain yang menerima lebih lanjut hak dari pihak yang menerima hak tersebut secara sah.

\section{Desain dan Teknologi}

${ }^{26}$ UU No 28 Tahun 2014 tentang Hak Cipta. 
Pembinaan dan pengembangan UMKM di bidang desain dan teknologi, dilaksanakan dengan:

a. meningkatkan kemampuan di bidang teknologi produksi dan pengendalian mutu;

b. meningkatkan kemampuan di bidang penelitian untuk mengembangkan desain dan teknologi baru;

c. memberikan intensif kepada usaha kecil yang menerapkan teknologi baru dan melestarikan lingkungan hidup;

d. meningkatkan kerjasama dan alih teknologi;

e. meningkatkan kemampuan dalam memenuhi standardisasi teknologi;

f. menumbuhkan dan mengembangkan lembaga penelitian dan pengembangan di bidang desain dan teknologi bagi usaha kecil;

g. menyediakan tenaga konsultan profesional di bidang teknologi;

h. memberikan bimbingan dan konsultasi berkenaan dengan kekayaan intelektual.

Pengembangan UMKM dibidang Desain yang dilakanakan sesuai poin $\mathrm{b}, \mathrm{f}$, dan $\mathrm{h}$ berpotensi mendapat hak desain industri ${ }^{27}$ karena merupakan "suatu kreasi tentang bentuk, konfigurasi, atau komposisi garis atau warna, atau garis dan warna, atau gabungan daripadanya yang berbentuk tiga dimensi atau dua dimensi yang memberikan kesan estetis dan dapat diwujudkan dalam pola tiga dimensi atau dua dimensi serta dapat dipakai untuk menghasilkan suatu produk, barang, komoditas industri, atau kerajinan tangan".

Untuk memperoleh Hak Desain Industri memerlukan pendaftaran (prinsip konstituti) dengan syarat bahwa kreasi berbentuk Desain Industri harus memiliki aspek kebaruan, dalam arti apabila pada Tanggal Penerimaan, Desain Industri tersebut tidak sama dengan pengungkapan yang telah ada sebelumnya. Pengungkapan sebelumnya, adalah pengungkapan Desain Industri yang sebelum :

a. tanggal penerimaan; atau

b. tanggal prioritas apabila Permohonan diajukan dengan Hak Prioritas;

c. telah diumumkan atau digunakan di Indonesia atau di luar Indonesia.

Suatu Desain Industri tidak dianggap telah diumumkan apabila dalam jangka waktu paling lama 6 (enam) bulan sebelum Tanggal Penerimaannya, Desain Industri tersebut : a. telah dipertunjukkan dalam suatu pameran nasional ataupun internasional di Indonesia atau di luar negeri yang resmi atau diakui sebagai resmi; atau b. telah digunakan di Indonesia oleh Pendesain dalam rangka percobaan dengan tujuan pendidikan, penelitian, atau pengembangan.

Dengan demikian, pengembangan UMKM akan mendapat perlindungan dalam bentuk hak desain industri, apabila kreasi tersebut memiliki aspek kebaruan dan Desain Industri tersebut tidak bertentangan dengan peraturan perundang-undangan yang berlaku, ketertiban umum, agama, atau kesusilaan. Perlindungan terhadap Hak Desain Industri diberikan untuk jangka waktu 10 (sepuluh) tahun (tidak dapat diperpanjang) terhitung sejak Tanggal Penerimaan. Tanggal mulai berlakunya jangka waktu perlindungan dicatat dalam Daftar $\mathrm{Umum}^{28}$ Desain Industri dan diumumkan

${ }^{27}$ UU No 31 Tahun 2000 tentang Desain Industri.

28 "Daftar Umum Desain Industri" adalah sarana penghimpunan pendaftaran yang dilakukan dalam bidang Desain Industri yang memuat keterangan tentang nama pemegang hak, jenis desain, tanggal diterimanya permohonan, tanggal pelaksanaan pendaftaran, danketerangan lain tentang 
dalam Berita Resmi Desain Industri ${ }^{29}$. Hak Desain Industri adalah hak eksklusif yang diberikan oleh negara Republik Indonesia kepada Pendesain atas hasil kreasinya untuk selama waktu tertentu melaksanakan sendiri, atau memberikan persetujuannya kepada pihak lain untuk melaksanakan hak tersebut.

Pengembangan UMKM berkaitan dengan teknologi yang dilaksanakan sesuai poin a, c, d, e, g, dan h berpotensi untuk dilindungi Paten ${ }^{30}$ karena "Paten adalah hak eksklusif yang diberikan oleh negara kepada inventor atas hasil invensinya di bidang teknologi untuk jangka waktu tertentu melaksanakan sendiri invensi tersebut atau memberikan persetujuan kepada pihak lain untuk melaksanakannya." Invensi adalah ide inventor yang dituangkan ke dalam suatu kegiatan pemecahan masalah yang spesifik di bidang teknologi berupa produk atau proses, atau penyempurnaan dan pengembangan produk atau proses.

Invensi tidak mencakup:

a. kreasi estetika;

b. skema;

c. aturan dan metode untuk melakukan kegiatan:

1. yang melibatkan kegiatan mental;

2. permainan;

3. bisnis.

d. aturan dan metode yang hanya berisi program komputer;

e. presentasi mengenai suatu informasi; dan

f. temuan (discovery) berupa:

1. penggunaan baru untuk produk yang sudah ada dan/ atau dikenal; dan/atau

2. bentuk baru dari senyawa yang sudah ada yang tidak menghasilkan peningkatan khasiat bermakna dan terdapat perbedaan struktur kimia terkait yang sudah diketahui dari senyawa.

UMKM dapat diberikan paten atau paten sederhana setelah melakukan pendaftaran (prinsip konstitutif) sebagaimana tersurat dalam syarat dan tata cara permohonan sebagaimana diatur dalam Pasal 24 sampai dengan Pasal 45 UU No 13 Tahun 2016. Apabila memenuhi persyaratan berdasarkan UU Paten yaitu pelindungan Paten diberikan untuk Invensi yang baru, mengandung langkah inventif, dan dapat diterapkan dalam industri. Sedangkan Paten sederhana diberikan untuk setiap Invensi baru, pengembangan dari produk atau proses yang telah ada, dan dapat diterapkan dalam industri, serta tidak mensyaratkan adanya langkah inventif.

Invensi dianggap baru jika pada Tanggal Penerimaan, Invensi tersebut tidak sama dengan teknologi yang diungkapkan sebelumnya. Teknologi yang diungkapkan sebelumnya merupakan teknologi yang telah diumumkan di Indonesia atau di luar Indonesia dalam suatu tulisan, uraian lisan atau melalui peragaan, penggunaan, atau dengan cara lain yang memungkinkan seorang ahli untuk melaksanakan Invensi tersebut sebelum: a. Tanggal Penerimaan; atau b. tanggal prioritas dalam hal Permohonan diajukan dengan Hak Prioritas. Teknologi yang diungkapkan sebelumnya mencakup dokumen Permohonan lain yang diajukan di Indonesia yang dipublikasikan

pengalihan hak (bilamana pemindahan hak sudah pernah dilakukan). Lihat Penjelasan Pasal 5 Ayat (2) UU No 31 Tahun 2000 tentang Desain Industri.

29 "Berita Resmi Desain Industri" adalah sarana pemberitahuan kepada masyarakat dalam bentuk lembaran resmi yang diterbitkan secara berkala oleh Direktorat Jenderal yang memuat hal-hal yang diwajibkan oleh Undang-undang ini.

${ }^{30}$ UU No 13 Tahun 2016 tentang Paten. 
pada atau setelah Tanggal Penerimaan yang pemeriksaan susbtantifnya sedang dilakukan, tetapi Tanggal Penerimaan tersebut lebih awal daripada Tanggal Penerimaan atau tanggal prioritas Permohonan. Dikecualikan dari ketentuan tersebut, Invensi tidak dianggap telah diumumkan jika dalam waktu paling lama 6 (enam) bulan sebelum Tanggal Penerimaan, Invensi telah:

a. dipertunjukkan dalam suatu pameran resmi atau dalam suatu pameran yang diakui sebagai pameran resmi, baik yang diselenggarakan di Indonesia maupun di luar negeri;

b. digunakan di Indonesia atau di luar negeri oleh Inventornya dalam rangka percobaan dengan tujuan penelitian dan pengembangan; dan/atau

c. diumumkan oleh Inventornya dalam:

1. sidang ilmiah dalam bentuk ujian dan/atau tahap ujian skripsi, tesis, disertasi, atau karya ilmiah lain; dan/atau

2. forum ilmiah lain dalam rangka pembahasan hasil penelitian di lembaga pendidikan atau lembaga penelitian. Invensi juga tidak dianggap telah diumumkan apabila dalam waktu 12 (dua belas) bulan sebelum Tanggal Penerimaan, ada pihak lain yang mengumumkan dengan cara melanggar kewajiban untuk menjaga kerahasiaan Invensi tersebut.

Invensi mengandung langkah inventif jika Invensi tersebut bagi seseorang yang mempunyai keahlian tertentu di bidang teknik merupakan hal yang tidak dapat diduga sebelumnya. Untuk menentukan suatu Invensi merupakan hal yang tidak dapat diduga sebelumnya harus dilakukan dengan memperhatikan keahlian yang ada pada saat Permohonan diajukan atau yang telah ada pada saat diajukan permohonan pertama dalam hal Permohonan itu diajukan dengan Hak Prioritas.

Invensi dapat diterapkan dalam industri jika Invensi tersebut dapat dilaksanakan dalam industri sebagaimana diuraikan dalam Permohonan.

Invensi yang tidak dapat diberi Paten meliputi:

a. proses atau produk yang pengumuman, penggunaan, atau pelaksanaannya bertentangan dengan peraturan perundang-undangan, agama, ketertiban umum, atau kesusilaan;

b. metode pemeriksaan, perawatan, pengobatan dan/atau pembedahan yang diterapkan terhadap manusia dan/atau hewan;

c. teori dan metode di bidang ilmu pengetahuan dan matematika;

d. makhluk hidup, kecuali jasad renik; atau

e. proses biologis yang esensial untuk memproduksi tanaman atau hewan, kecuali proses nonbiologis atau proses mikrobiologis.

Jangka Waktu Pelindungan Paten diberikan untuk jangka waktu 20 (dua puluh) tahun terhitung sejak Tanggal Penerimaan. Jangka waktu tersebut tidak dapat diperpanjang. Tanggal mulai dan berakhirnya jangka waktu Paten dicatat dan diumumkan melalui media elektronik dan/atau media non-elektronik. Paten sederhana diberikan untuk jangka waktu 10 (sepuluh) tahun terhitung sejak Tanggal Penerimaan. Jangka waktu tersebut tidak dapat diperpanjang. Tanggal mulai dan berakhirnya jangka waktu Paten sederhana dicatat dan diumumkan melalui media elektronik dan/atau media non-elektronik.

Pembinaan dan pengembangan usaha kecil oleh pemerintah yang dilaksanakan oleh Menteri dan Menteri Teknis sesuai dengan bidang tugas masing-masing berupa: 
a. pemberian kesempatan dalam pengadaan barang dan jasa yang diperlukan pemerintah;

b. pencadangan usaha bagi usaha kecil;

c. penyederhanaan dan kemudahan perijinan;

d. penyediaan tenaga konsultan profesional;

e. penyediaan dana;

f. penyediaan teknologi dan informasi;

g. penyediaan sarana dan prasarana;

h. pendirian klinik konsultasi bisnis untuk usaha kecil.

Menteri dan atau Menteri Teknis menyiapkan secara terpadu kebijakan pencadangan usaha bagi usaha kecil, yang meliputi:

a. pencadangan bidang usaha dan investasi tertentu di sektor perdagangan, jasa, pertanian, industri, pertambangan, dan konstruksi;

b. pencadangan tempat dan lokasi usaha;

c. pencadangan jenis kegiatan usaha yang memiliki kekhususan proses, bersifat padat karya serta mempunyai nilai budaya yang bersifat turun temurun.

Pembinaan dan pengembangan usaha kecil yang dilaksanakan oleh dunia usaha dan masyarakat, berupa:

a. penyediaan tenaga konsultan profesional, sarana, prasarana, dana, teknologi dan informasi;

b. bimbingan dan konsultasi;

c. pendidikan dan pelatihan;

d. advokasi;

e. pendirian klinik konsultasi bisnis untuk usaha kecil.

Pemerintah, dunia usaha dan masyarakat menyediakan pembiayaan dan penjaminan serta bantuan perkuatan bagi usaha kecil untuk kelancaran pelaksanaan pembinaan dan pengembangan usaha kecil, melalui lembaga pendukung yang terdiri dari:

a. lembaga pembiayaan;

b. lembaga penjaminan;

c. lembaga pendukung lain.

Lembaga pembiayaan memberikan prioritas pelayanan, kemudahan dan akses dalam memperoleh pendanaan bagi usaha kecil yang dibina dan dikembangkan melalui:

a. penyediaan pendanaan usaha kecil;

b. penyederhanaan tata cara dalam memperoleh pendanaan dengan memberikan kemudahan dalam pengajuan permohonan dan kecepatan memperoleh keputusan;

c. pemberian keringanan persyaratan jaminan tambahan;

d. penyebarluasan informasi mengenai kemudahan untuk memperoleh pendanaan untuk usaha kecil melalui penyuluhan langsung dan media massa yang ada;

e. penyelenggaraan pelatihan membuat rencana usaha dan manajemen keuangan;

f. pemberian keringanan tingkat bunga kredit usaha kecil;

g. bimbingan dan bantuan usaha kecil;

h. loket khusus untuk pelayanan dan informasi kredit usaha kecil. 
Lembaga penjaminan memberikan prioritas pelayanan dan kemudahan dan akses bagi usaha kecil yang dibina dan dikembangkan untuk memperoleh jaminan pendanaan melalui:

a. perluasan fungsi lembaga penjaminan yang sudah ada dan atau pembentukan lembaga penjaminan baru;

b. pembentukan lembaga penjamin ulang untuk menjamin lembaga-lembaga penjaminan yang ada.

Lembaga pendukung lain berperan mempersiapkan dan menjembatani pembinaan dan pengembangan usaha kecil melalui:

a. penyediaan informasi, bantuan manajemen dan teknologi kepada usaha kecil;

b. pemberian bimbingan dan konsultasi melalui klinik konsultasi bisnis kepada usaha kecil;

c. pelaksanaan advokasi kepada berbagai pihak untuk kepentingan usaha kecil;

d. pelaksanaan magang, studi banding dan praktek kerja bagi usaha kecil.

Pembinaan dan pengembangan UMKM tidak terlepas dari perlunya melakukan inovasti dan kreatif terhadap suatu produk atau pemasaran yang relevan dengan potensi mendapatkan perlindungan kekayaan intelektual. Oleh karena beberapa KI mensyaratkan "aspek kebaruan", "aspek pembeda", "aspek keaslian" sehingga UMKM akan termotivasi menghasilkan kreasi produk yang mengandung aspekaspek tersebut. Di sisi lain adanya kemungkinan pemegang KI (pelaku usaha UMKM) dapat melisensikan KI-nya merupakan strategi pengembangan bisnis yang menghasilkan keuntungan (royalti) untuk menopang modal yang sudah ada dalam mengembangkan diversifikasi usahanya. Namun beberapa hasil penelitian yang telah dilakukan menyimpulkan bahwa terdapat beberapa hambatan bagi UMKM untuk menganggap penting keberadaan KI dalam kreasi atau produk yang dihasilkannya. Dari Hasil survei lapangan dapat disimpulkan sebagai berikut: ${ }^{31}$

1. Rata-rata responden pernah mendengar KI (100,00\%), tetapi belum mengerti arti dan pentingnya, serta prosedur pengajuan administrasi.

2. Rata-rata responden mengatakan tanpa KI perusahaan tetap jalan $(75,00 \%)$. Usaha dikelola kecil-kecil dan diantaranya ada usaha yang turun-temurun.

3. Rata-rata responden mengatakan kurang berminat memiliki KI $(52,50 \%)$, dan tidak berminat $(45,25 \%)$. Ini disebabkan biaya dikeluarkan akan mengganggu kelancaran usaha.

4. Hasil jajak pendapat dilapangan (survei responden) mengatakan, menunggu penyuluhan tentang KI dari pemerintah dan instansi terkait.

Di kalangan UMKM pemahaman terhadap Kekayaan Intelektual, misalnya untuk merek sudah ada meskipun ada beberapa yang memakai istilah label yaitu tanda untuk membedakan produk yang sejenis, mekipun demikian ada beberapa UMKM yang tidak memperdulikan pemakaian merek karena: pertama, kualitas barang merupakan faktor terpenting dalam penjualan produk yang dihasilkan, hal ini disebabkan para pelaku UMKM berkedudukan sebagai pabrikan (produsen) sehingga produk mereka dibeli dalam jumlah banyak (sebagai tempat kulakan), kemudian para pembeli ini akan memberi merek sesuai yang dimiliki. Kedua, persepsi bahwa proses pendaftaran merek dianggap "ribet" dan mahal. Hal ini menyebabkan beberapa

${ }^{31}$ Nurhasanah Harahap, "Relevansi Hak Kekayaan Intelektual Untuk Usaha Kecil Menengah (UKM)", tersedia dari https://nurhasanahharahap25212492.wordpress.com/2014/04/11/relevansi-hakkekayaan-intelektual-untuk-usaha-kecil-menengah-ukm diakses 6 Januari 2021. 
UMKM sudah memberi merek, untuk produk yang dihasilkan tetapi tidak melakukan pendaftaran. Sedangkan untuk desain industri, desain dari produk pelaku UMKM sebagaimana berasal dari pihak pemesan, sebagian kreasi sendiri (dengan catatan meniru produk yang sedang laku atau baru) produk lama saja diberi tambahan berupa ornament sehingga pendaftaran desain dianggap tidak perlu mengingat unsur "baru" tidak terpenuhi. ${ }^{32}$

Hal itu menunjukan pentingnya upaya pelaku UMKM agar "Kekayaan Intelektual minded", artinya memiliki pemikiran bahwa kreasi dan inovasi yang dihasilkannya perlu mendapatkan pengakuan sebagai pemilik Kekayaan Intelektual untuk menunjang pengembangan usahanya. Hal ini mengingat adanya pelindungan Kekayaan Intelektual terhadap pelaku UMKM selain memberikan kepastian hukum, juga memperoleh hak-hak yang diberikan dalam pengembangan usahanya.

Keberadaan UU berkaitan dengan Kekayaan Intelektual mendukung pelaku UMKM yang memiliki potensi untuk mendapatkan pelindungan kreasi dan inovasinya. Dukungan legislasi pengembangan UMKM dalam perspektif pelindungan untuk mendapatkan Kekayaan Intelektual, yaitu: ${ }^{33}$

a. Biaya registrasi Kekayaan Intelektual UMKM yang lebih murah dibandingkan Non-UMKM;

b. Kerjasama antara Ditjen KI Kementerian Hukum dan HAM dan Kementerian Koperasi dan UMKM;

Upaya yang telah dilakukan untuk memberikan perlindungan Merek dagang produksi industri UMKM diadakan Kerjasama antara Departemen Hukum dan HAM RI dengan Kementrian Koperasi dan Usaha Kecil Dan Menengah RI Nomor M-10-UM .06.07.TH 2006 tentang Peningkatan Pemahaman dan Pemanfaatan Sistem Kekayaan Intelektual bagi Koperasi dan UMKM. Adapun pertimbangan diadakan kerjasama tersebut adalah sebagai berikut: 1) UMKM merupakan salah satu pelaku usaha yang memiliki kontribusi yang nyata dalam perekonomian nasional. 2) Pengetahuan dan pemahaman mengenai keberadaan dan pentingnya pemanfaatan sistim Kekayaan Intelektual di kalangan pelaku UMKM sektor industri baik makanan, miniman maupun barang-barang produksi olahan rumah tangga masih perlu disosialisasikan. 3) Koordinasi dan kerjasama yang sinergi antara para pihak dan upaya peningkatan penyebarluasan, pemahaman dan pemanfaatan sistem Kekayaan Intelektual belum optimal dalam perlindungan merek dagang produk makanan.

Tujuan diadakan kerjasama antara Departemen Hukum dan HAM RI dengan Kementrian Negara Koperasi dan Usaha Kecil Menengah adalah: 1) Meningkatkan pengetahuan dan pemahaman serta pemanfaatan sistim KI dikalangan pelaku UMKM. 2) Mewujudkan UMKM berorientasi KI, memiliki kualitas dan daya saing yang tinggi dalam persaingan global. 3) Meningkatkan koordinasi dan kerjasama yang sinergis dan produktif antara para pihak dalam mengembangkan UMKM dan memberdayakan sistim Kekayaan Intelektual (KI) nasional.

c. Pemberian Intensif Pembiayaan Pendaftaran KI untuk UMKM

32 Inayah, Kesadaran Hukum Pelaku Usaha Mikro Kecil Menegah (UMKM) Dalam Perlindungan Kekayaan Intelektual, Jurnal Law And Justice Vol. 4, No. 2, 2019, pp.26-xxx e-ISSN : 2549-8282 Website: http://journals.ums.ac.id/index.php/laj, hlm 134, diakses 3 Februari 2021.

${ }^{33}$ Bandingkan dengan Andrew Betlehn, Upaya Perlindungan Hukum Terhadap Merek Industri UMKM Di Indonesia, Jurnal Law and Justice, Volume 3, Nomor 1, April 2018. 
Dasar hukum Keputusan Direktur Jenderal Hak Kekayaan Intelektual Kementerian Hukum dan Hak Asasi Manusia RI Nomor HKI-09.OT.03.01 Tahun 2013 tentang Insentif Hak Kekayaan Intelektual Bagi Sekolah Menengah Perguruan Tinggi, Usaha Mikro dan Usaha Kecil serta Warga Binaan Pemasyarakatan Tahun 2013.

\section{KESIMPULAN}

Pengembangan UMKM berdasarkan hukum positif dilakukan oleh Pemerintah dan Pemerintah Daerah dalam memfasilitasi bidang: a. produksi dan pengolahan; $b$. pemasaran; c. sumber daya manusia; dan d. desain dan teknologi. Sedangkan dunia usaha dan masyarakat berperan serta secara aktif melakukan pengembangan yang mencakup tata cara pengembangan, prioritas, intensitas, dan jangka waktu pengembangan. Pemerintah, dunia usaha dan masyarakat menyediakan pembiayaan dan penjaminan serta bantuan perkuatan bagi usaha kecil untuk kelancaran pelaksanaan pembinaan dan pengembangan usaha kecil, melalui lembaga pendukung yang terdiri dari: a. lembaga pembiayaan; b. lembaga penjaminan; c. lembaga pendukung lain. Selanjutnya, dukungan terhadap pengembangan UMKM yang memiliki potensi kekayaan Intelektual adalah memberikan kebijakan melalui biaya registrasi yang lebih murah dibandingkan non UMKM, Kerjasama antara Ditjen KI Kementerian Hukum dan Ham dan Kementerian Koperasi dan UMKM dan Pemberian Intensif Pembiayaan Pendaftaran KI untuk UMKM

\section{SARAN}

Potensi UMKM berkaitan dengan "produksi dan pengolahan" adalah mendapatkan hak Rahasia Dagang, apabila dijaga kerahasiannya. Bidang UMKM "pemasaran" berpotensi untuk mendapat hak merek jika kreasi tersebut memiliki daya pembeda dengan merek lain. Bidang UMKM “ sumber daya manusia" berpotensi mendapat Hak Cipta, apabila kreasi tersebut berkaitan dengan ilmu pengetahuan, seni dan sastera yang bersifat tersebut asli "bukan hasil peniruan" dan telah berwujud (bukan ide). Bidang UMKM“ desain dan teknologi” berpotensi mendapatkan Hak Desain Industri, apabila desain tersebut mempunyai aspek kebaruan sedangkan hak paten akan diberikan apabila "teknologi" tersebut memiliki aspek kebaruan, langkah inventif dan dapat diterapkan dalam industri.

Untuk menjamin kepastian hukum perlu segera disahkan Peraturan Pelaksanaan UU No 20 Tahun 2008 Tentang UMKM. Selanjutnya, Pemerintah dan pemangku kepentingan lainnya perlu memberikan pemahaman melalui penerangan atau sosialisasi kepada UMKM tentang bidang usaha yang berpotensi mendapat perlindungan kekayaan intelektual dan kemudahan serta insentif biaya pendaftaran KI-nya. 


\section{DAFTAR PUSTAKA}

\section{A. Buku}

Afifuddin, Pengantar Administrasi Pembangunan, Bandung : CV Alfabeta, 2010.

Andrian, Krisnawati dan Gazalba Saleh, Perlindungan Hak Varietas Tanaman Baru Dalam Prespektif Hak Paten dan Hak Pemuliaan Tanaman, Jakarta: PT. Raja Grafindo Persada, 2004.

David, F.R, Manajemen Strategi; Konsep , Edisi Kesepuluh, Jakarta: Salemba Empat, 2006.

Djasuro Surya, Manajemen Koperasi dan UKM, Serang: Untirta Press, 2015.

Kuncoro, M, Strategi Bagaimana Meraih Keunggulan Kompetitif, Jakarta: Erlangga, 2005.

Musa Hubeis, Prospek Usaha Kecil Dalam Wadah Inkubator Bisnis, Bogor: Ghalia Indonesia, 2015.

Soerjono Soekanto dan Sri Mamudji, Penelitian Hukum Normatif Suatu Tinjauan Singkat, Cetakan ke-11, Jakarta : PT Raja Grafindo Persada, 2009.

Suyud Margono,Aspek Hukum Komersialisasi Aset Intelektual, Bandung: Penerbit Nuansa Aulia, 2010.

Tambunan, T, UMKM di Indonesia, Bogor : Ghalia, 2009.

Yoserwan, Hukum Ekonomi Indonesia, Dalam Era Reformasi dan Globalisasi, Padang: Andalas University Press, 2006.

\section{B. Undang-Undang}

Undang-Undang Nomor 30 Tahun 2000 tentang Rahasia Dagang

Undang-Undang Nomor 20 Tahun 2016 tentang Merek dan Indikasi Geografis

Undang-Undang Nomor 28 Tahun 2014 tentang Hak Cipta

Undang-Undang Nomor 31 Tahun 2000 tentang Desain Industri

Undang-Undang Nomor 13 Tahun 2016 tentang Paten

Undang-Undang Nomor 20 Tahun 2008 tentang Usaha Mikro, Kecil dan Menengah.

\section{Jurnal, Makalah dan Sumber Digital (Internet)}

Alyas dan Muhammad Rakib, "Strategi Pengembangan Usaha Mikro, Kecil Dan Menengah Dalam Penguatan Ekonomi Kerakyatan" (Studi Kasus pada Usaha Roti Maros di Kabupaten Maros), Jurnal Sosiohumaniora, Volume 19 No. 2 Juli, 2017.

Andrew Betlehn, Upaya Perlindungan Hukum Terhadap Merek Industri UMKM Di Indonesia, Jurnal Law and Justice, Volume 3, Nomor 1, April 2018. 
Ariza Fuadi, "Negara Kesejahteraan (Welfare State) Dalam Pandangan Islam Dan Kapitalisme", Jurnal Ekonomi Syariah Indonesia, Volume V, No.1 Juni 2015, tersedia dari ejournal.umm.ac.id/index.php/JES/article/view/8741diakses 23 Desember 2020.

Gunartin, "Penguatan UMKM Sebagai Pilar Membangun Ekonomi Bangsa", EDUKA Jurnal Pendidikan, Hukum dan Bisnis Vol.1 No. V Desember 2017.

Hikman Dwi R, 3 “Alasan Mengapa UMKM Penting bagi Perekonomian Indonesia”, tersedia dari https://kumparan.com/hikman-dwi-r/3-peran-penting-umkmpenggerak-sektor-ekonomi-indonesia-di-tingkat-menengah-ke-bawah, 2028. diakses 12 Desember 2020.

Inayah, Kesadaran Hukum Pelaku Usaha Mikro Kecil Menegah (UMKM) Dalam Perlindungan Kekayaan Intelektual, Jurnal Law And Justice Vol. 4, No. 2, 2019, pp.26-xxx e-ISSN : 2549-8282 Website: http://journals.ums.ac.id/index. php/laj diakses 3 Februari 2021.

Laurensius Arliman S, Perlindungan hukum UMKM dari eksploitasi ekonomi dalam rangka peningkatan kesejahteraan masyarakat, jurnal rechvinding, Media Pembinaan Hukum Nasional, Volume 6, Nomor 3, Desember, 2017. tersedia dari https://rechtsvinding. bphn.go.id/artikel/05\%20 Laurensius\%20 Arliman.pdf diakses 7 Januari 2021.

Nurhasanah Harahap, "Relevansi Hak Kekayaan Intelektual Untuk Usaha Kecil Menengah (UKM)", tersedia dari https://nurhasanahharahap 25212492.wordpress.com/ 2014/04/11/relevansi-hak-kekayaan-intelektualuntuk-usaha-kecil-menengah-ukm diakses 6 Januari 2021.

Sudaryanto dkk, "Strategi Pemberdayaan UMKM Menghadapi Pasar Bebas Asean", Jurnal Kementrian Keuangan Republik Indonesia (DI) tersedia dari https://www.kemenkeu.go.id/sites/default/files/strategi\%20pemberdayaan\%2 Oumkm.pdf diakses 6 Januari 2021.

Oman Sukmana, "Konsep dan Desain Negara Kesejahteraan (Welfare State)", Jurnal Sospol, $\quad$ Vol 2 No.1 (Juli-Desember) 2016, http://ejournal.umm.ac.id/index.php/sospol/article/view/4759/4900 diakses 21 Desember 2018.

http: //krjogja.com/web/news/read/55319/ Begini_Peranan_UMKM_dalam _Perekonomian_Nasional. diakses 6 Desember 2020.

https://idtesis.com/pengertian-penelitian-hukum-normatif-adalah/ diakses 15 Desember 2020.

https://www.liputan6.com/bisnis/read/3581067/umkm-sumbang-60-persen-kepertumbuhan-ekono -mi- nasional. diakses 10 Desember 2020. 